\title{
Fertilizer Placement Affects Weed Growth and Grain Yield in Dry-Seeded Rice (Oryza sativa L.) Systems
}

\author{
Bhagirath S. Chauhan*, Seth B. Abugho \\ Crop and Environmental Sciences Division, International Rice Research Institute, Los Baños, Philippines. \\ Email: *b.chauhan@irri.org
}

Received April 20 ${ }^{\text {th }}, 2013$; revised May 21 ${ }^{\text {st }}, 2013$; accepted June $9^{\text {th }}, 2013$

Copyright (C) 2013 Bhagirath S. Chauhan, Seth B. Abugho. This is an open access article distributed under the Creative Commons Attribution License, which permits unrestricted use, distribution, and reproduction in any medium, provided the original work is properly cited.

\begin{abstract}
A study was conducted in a split-plot design to evaluate the effect of fertilizer placement method on weed growth and grain yield in a dry-seeded rice (DSR) system. Main-plot treatments were four fertilizer placement methods: between narrow rows (between 15-cm-wide rows of the pattern 25-15-25 cm), between uniform rows (between 20-cm-wide rows), within uniform rows, and surface broadcast. Subplot treatments were three weed control methods: herbicide-treated, nontreated, and weed-free. Weed biomass was greater in the nontreated plots than in the herbicide-treated plots. Herbicide application reduced weed biomass by $89 \%$ to $99 \%$ compared with the nontreated control. Fertilizer placement did not influence weed biomass in the herbicide-treated plots; however, it greatly influenced biomass in the nontreated plots. Fertilizer placement on the surface increased weed biomass $\left(69-71 \mathrm{~g} \cdot \mathrm{m}^{-2}\right)$ compared with the placement of fertilizer below the soil surface $\left(37-57 \mathrm{~g} \cdot \mathrm{m}^{-2}\right)$. Fertilizer placement did not influence weed density and biomass at 60 days after planting. Nontreated plots yielded 700 to $2080 \mathrm{~kg} \cdot \mathrm{ha}^{-1}$. Grain yield was similar between the herbicide-treated $\left(2660-3250 \mathrm{~kg} \cdot \mathrm{ha}^{-1}\right)$ and weed-free $\left(2620-3430 \mathrm{~kg} \cdot \mathrm{ha}^{-1}\right)$ plots. Grain yield was not influenced when basal fertilizer was banded within $\left(2390-2500 \mathrm{~kg} \cdot \mathrm{ha}^{-1}\right)$ or between rows $\left(2530-2650 \mathrm{~kg} \cdot \mathrm{ha}^{-1}\right)$. However, grain yield decreased when basal fertilizer was broadcast on the soil surface $\left(2200 \mathrm{~kg} \cdot \mathrm{ha}^{-1}\right)$. The results of our study demonstrated that rice yield was usually lower with surface broadcast of fertilizer than with subsurface fertilizer treatments. In conclusion, surface broadcast of basal fertilizer may result in high weed pressure in DSR systems.
\end{abstract}

Keywords: Nitrogen; Fertilizer; Weed Biomass; Weed Density; Placement; Asia

\section{Introduction}

Rice (Oryza sativa L.) is an important staple crop in Asia. Growers in many Asian countries (e.g., Philippines and India) are shifting their production systems from traditional puddled-transplanted rice to seeded rice, especially dry-seeded rice. The main reasons for this shift are labor and water scarcities $[1,2]$. In many regions, it is also difficult to find laborers at the critical time of transplanting. Dry-seeded rice (DSR) has several advantages: it is less labor-intensive, consumes less water, is more easily and rapidly planted, has fewer methane emissions, and is conducive to mechanized seeding [1]. However, this production system is not without limitations. Weeds are the main biological constraint in DSR systems as weed and rice seedlings emerge simultaneously and there is no standing water to suppress weeds at the time of crop

"Corresponding author. emergence [3]. Herbicides are widely used to manage weeds in DSR systems.

In Asia, growers in DSR systems usually broadcast basal fertilizer before crop planting. The main reasons for surface broadcast are a lack of appropriate seed drills to band fertilizer at optimum position in the soil and limited options of fertilizers [e.g., phosphorus (P) and potassium $(\mathrm{K})]$ with uniform size of granules, which can be used in seed drills. Fertilizer placement is considered one of the important components of cultural weed management programs [4] as fertilizer placement can markedly influence the competitive ability of crops and interference from weeds [5]. In previous studies, placement of fertilizer below the soil surface improved wheat (Triticum aestivum L.) growth and reduced weed emergence and weed growth compared with placement on the soil surface [4-8].

In Canada, nitrogen $(\mathrm{N})$ application method had larger 
effects than $\mathrm{N}$ application timing on weed growth and wheat yield [9]. In that study, shoot $\mathrm{N}$ concentration and biomass of weeds were lower with banded $\mathrm{N}$ than with surface-broadcast $\mathrm{N}$. In another study, band placement of fertilizer (blend of N, P, and $\mathrm{K}$ ) reduced the growth of grass and broadleaf weeds in soybean (Glycine max L.) and groundnut (Arachis hypogaea L.) by more than $40 \%$ compared with surface-broadcast fertilizer [10]. The information from several studies suggests that manipulation of fertilizer placement is a promising weed management approach to reduce weed competition in crops $[5,9]$. In the future, banding of fertilizer rather than surface broadcast could also help to reduce fertilizer rates and increase fertilizer-use efficiency.

Most of the information on the effect of fertilizer placement on weeds is available from the Americas. Very limited information is available in the literature from Asian regions, especially in DSR systems. As DSR is an emerging production system in Asia, information on the effect of fertilizer placement on weed and crop growth may help researchers, manufacturers, and farmers to manipulate fertilizer placement to achieve high grain yield. Therefore, a field study was conducted to evaluate the effect of fertilizer placement on weed growth and grain yield of rice in a dry-seeded system.

\section{Materials and Methods}

A study was conducted in irrigated conditions during the dry and wet seasons of 2012 on the farm of the International Rice Research Institute, Los Baños, Philippines, to evaluate the effect of fertilizer placement on weed growth and grain yield in a DSR system. Soil at the experimental site had sand, silt, and clay contents of 28,43 and $29 \%$, respectively. The maximum and minimum temperatures $\left({ }^{\circ} \mathrm{C}\right)$, and total rainfall $(\mathrm{mm})$ recorded at the experimental site are shown in Figure 1. The experimental site was rotovated twice using a 4-wheel tractor before crop planting and then it was leveled using a wooden board.

The experiment was arranged in a split-plot design with four replications in each season. Main-plot treatments were four fertilizer placement methods: 1) between narrow rows (fertilizer incorporated $5-\mathrm{cm}$ deep between $15-\mathrm{cm}$-wide rows of the pattern $25-15-25 \mathrm{~cm}$, i.e., paired rows), 2) between uniform rows (between 20$\mathrm{cm}$-wide rows), 3) within uniform rows (below seed), and (4) surface broadcast (before crop planting). In the broadcast method, fertilizer was applied before the last land preparation operation. A complete fertilizer (14:14:14 of $\mathrm{N}: \mathrm{P}_{2} \mathrm{O}_{5}: \mathrm{K}_{2} \mathrm{O}$ ) was used for the basal dose at $42 \mathrm{~kg} \mathrm{ha}^{-1}$ for each nutrient (i.e., $\mathrm{N}, \mathrm{P}_{2} \mathrm{O}_{5}$, and $\mathrm{K}_{2} \mathrm{O}$ ). After the application of fertilizer, rice (Rc222) was planted (January 10 and May 29, 2012) by hand at $50 \mathrm{~kg} \cdot \mathrm{ha}^{-1}$. The crop was planted at $20-\mathrm{cm}$ row spacing except in the paired- row pattern (25-15-25-cm row spacing). Subplot treatments were three weed control methods: (1) herbicidetreated [oxadiazon $\left(0.75 \mathrm{~kg} \cdot \mathrm{ai}^{\mathrm{i}} \cdot \mathrm{ha}^{-1}\right)$ at $1 \mathrm{~d}$ after planting (DAP) followed by a commercial mixture of fenoxaprop plus ethoxysulfuron $\left(0.45 \mathrm{~kg} \cdot \mathrm{ai}^{\mathrm{h}} \mathrm{ha}^{-1}\right)$ at $\left.21 \mathrm{DAP}\right]$, (2) nontreated (one hand weeding at 35 DAP in the dry season and at 60 DAP in the wet season), and (3) weed-free (hand weeding until rice flowering). Herbicides were applied with a knapsack sprayer that delivered $220 \mathrm{~L} \cdot \mathrm{ha}^{-1}$ of spray solution through flat-fan nozzles at a spray pressure of $140 \mathrm{kPa}$. Immediately after crop planting, the field was flush-irrigated and then irrigated as required by the crop. In the crop, N (as urea) was applied in two equal splits in all the treatments, that is, $56 \mathrm{~kg} \cdot \mathrm{N} \cdot \mathrm{ha}^{-1}$ at $35 \mathrm{DAP}$ and $56 \mathrm{~kg} \cdot \mathrm{N} \cdot \mathrm{ha}^{-1}$ at $60 \mathrm{DAP}$ (panicle initiation).

Total weed density and biomass were evaluated at 35 and 60 DAP by placing two $40-\mathrm{cm} \times 40-\mathrm{cm}$ quadrats in each plot. Weeds were uprooted from soil, washed with tap water, and then counted. Weed biomass was determined after drying the samples in an oven at $70 \mathrm{C}$ for 72 $\mathrm{h}$. The crop was harvested on May 2 and September 24, 2012, from a harvest area of $4.5 \mathrm{~m}^{2}$. Grain yield was converted to $\mathrm{kg} \cdot \mathrm{ha}^{-1}$ at $14 \%$ moisture content. Weed density and biomass data were subjected to transforma- tion; however, the transformation did not improve the homogeneity of variance. Therefore, original data were analyzed using ANOVA to evaluate differences between treatments, and the means were separated using LSD at $5 \%$ level of significance [11].

\section{Results and Discussion}

At 35 DAP, weed density was significantly influenced by fertilizer placement method in the dry season but not in the wet season (Table 1). In the dry season, maximum weed density was observed in the plots in which fertilizer had been broadcast; however, weed density in these plots was significantly higher than in the plots in which basal fertilizer was applied within uniform rows (20-cm spacing).

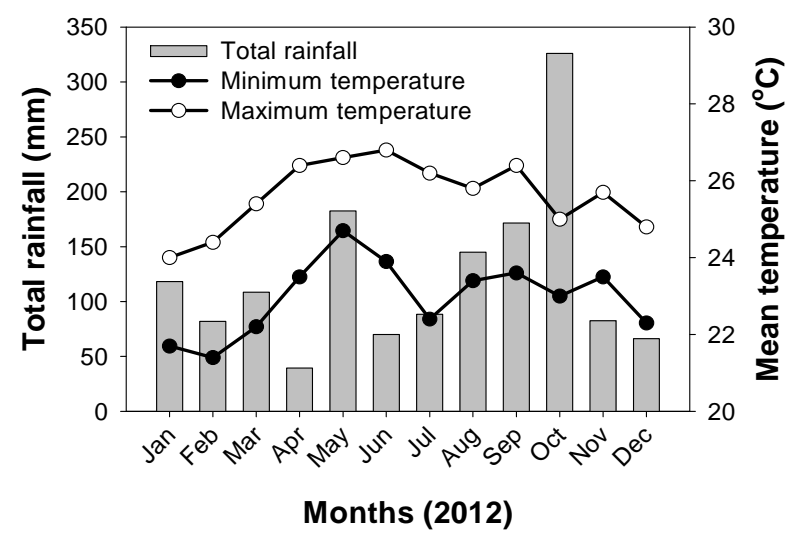

Figure 1. Mean maximum and minimum temperatures $\left({ }^{\circ} \mathrm{C}\right)$, and total rainfall $(\mathrm{mm})$ recorded at the experimental site. 
Although weed density in the wet season was highest in the plots fertilized with the broadcast method, the difference in density between different fertilizer placement methods was nonsignificant. Weed density declined significantly after herbicide application. In the herbicidetreated plots, weed density was 18 and 23 plants $\cdot \mathrm{m}^{-2}$ in the dry and wet seasons, respectively. These values in the nontreated plots were 379 and 599 plants $\cdot \mathrm{m}^{-2}$, respectively.

Weed biomass at 35 DAP was affected by the interaction between fertilizer placement method and weed control treatment in both seasons (Table 2). Weed biomass was always greater in the nontreated plots than in the herbicide-treated plots. Irrespective of the season and fertilizer placement method, herbicide application reduced weed biomass by $89 \%$ to $99 \%$ compared with the nontreated control. Fertilizer placement did not influence weed biomass in the herbicide-treated plots; however, it greatly influenced biomass in the nontreated plots (Table 2). In both seasons, fertilizer placement on the surface (i.e., broadcast) increased weed biomass compared with the placement of fertilizer below the soil surface. In the dry season, the broadcast treatment had $25 \%$ to $51 \%$ higher weed biomass than the other fertilizer placement methods and these values in the wet season were $39 \%$ to $86 \%$. The placement of fertilizer in the soil, whether applied between or within rows, did not influence weed biomass in the dry season. In the wet season, however, weed biomass was lower in the plots in which fertilizer was applied between narrow rows than within uniform rows (Table 2). The results of our study suggest that growers practicing broadcast fertilizer may experience increased weed problems, when they don't apply preemergence or early post-emergence herbicides, or when they are expecting poor weed control due to limited resources.

Table 1. Effect of fertilizer placement methods on weed density at $35 \mathrm{~d}$ after planting in dry-seeded rice in the dry (DS12) and wet seasons (WS12) of 2012.

\begin{tabular}{|c|c|c|}
\hline \multirow{3}{*}{ Fertilizer placement } & \multicolumn{2}{|c|}{ Weed density } \\
\hline & DS12 & WS12 \\
\hline & \multicolumn{2}{|c|}{$\longrightarrow$ no. $\mathrm{m}^{-2} \longrightarrow$} \\
\hline Between narrow rows & 192 & 253 \\
\hline Between uniform rows & 220 & 283 \\
\hline Within uniform rows & 137 & 316 \\
\hline Broadcast & 246 & 391 \\
\hline $\mathrm{LSD}_{0.05}$ & 71 & nonsignificant \\
\hline
\end{tabular}

Table 2. Interaction effect of herbicide and fertilizer placement method on weed biomass at $35 \mathrm{~d}$ after planting in dry-seeded rice in the dry (DS12) and wet seasons (WS12) of 2012.

\begin{tabular}{|c|c|c|c|c|}
\hline \multirow{4}{*}{ Fertilizer placement } & \multicolumn{4}{|c|}{ Weed biomass } \\
\hline & \multicolumn{2}{|c|}{ DS12 } & \multicolumn{2}{|c|}{ WS12 } \\
\hline & Nontreated & Treated & Nontreated & Treated \\
\hline & \multicolumn{4}{|c|}{$\overline{\mathrm{g} \cdot \mathrm{m}^{-2}} \overline{ }$} \\
\hline Between narrow rows & 51.7 & 2.5 & 37.0 & 3.5 \\
\hline Between uniform rows & 57.0 & 3.5 & 44.3 & 2.4 \\
\hline Within uniform rows & 47.2 & 0.5 & 49.7 & 5.5 \\
\hline Broadcast & 71.1 & 3.0 & 68.9 & 3.2 \\
\hline $\mathrm{LSD}_{0.05}$ & 12.0 & & 8.9 & \\
\hline
\end{tabular}

Our results are consistent with previous studies, in which placement of fertilizer below the soil surface reduced weed growth compared with placement on the soil surface [4-8]. Kirkland and Beckie [4] reported that broadcast-applied fertilizer was more effective than banded fertilizer in promoting wild oat (Avena fatua L.) and broadleaf weed emergence and growth in wheat. The authors also suggested that banding fertilizer at recommended rates can be an effective cultural practice for managing weeds in no-till and conventional tillage wheat-cropping systems; however, this method was not reliable when used as the sole method of weed management. In another study, wild oat and green foxtail [Setaria viridis (L.) Beauv.] had a competitive advantage over wheat by greater use of broadcast-applied N [7]. In barley (Hordeum vulgare $\mathrm{L}$.), too, there were fewer wild oat plants where $\mathrm{N}$ fertilizer was banded rather than broadcast [12]. Most of the previous studies used only $\mathrm{N}$ fertilizer as a basal dose; however, we used complete fertilizer (i.e., $\mathrm{N}$, $\mathrm{P}$, and $\mathrm{K}$ ). In Asia, growers usually apply $\mathrm{P}$ and $\mathrm{K}$ fertilizers before crop sowing and therefore our results are very much applicable for the region.

Fertilizer placement did not influence weed density and biomass at 60 DAP (data not shown). In our study, a second dose of $\mathrm{N}$ was broadcast in all treatments at 35 DAP and this is the common practice in Asia. It seems that $\mathrm{N}$ application at 35 DAP neutralized the effect of basal fertilizer placement on weed density and biomass at 60 DAP. Herbicide application, however, influenced weed density and biomass at 60 DAP. In the nontreated control, weed density was 102 and 652 plants $\cdot \mathrm{m}^{-2}$ in the dry and wet seasons, respectively. These values in the herbicide-treated plots were 37 and 50 plants $\mathrm{m}^{-2}$, respectively. In the dry season, weed biomass was 0.7 and 3.3 
$\mathrm{g} \cdot \mathrm{m}^{-2}$ in the herbicide-treated and nontreated plots, respectively. These values in the wet season were 20.2 and 328.7 $\mathrm{g} \cdot \mathrm{m}^{-2}$, respectively. Compared with the dry season, higher weed density and biomass in the nontreated plots in the wet season were due to late hand weeding.

In both seasons, grain yield was not influenced by the interaction between fertilizer placement and weed control treatment; however, it was significantly influenced by the individual treatments (Table 3). In both seasons, nontreated plots had significantly lower grain yield than the other plots. Nontreated plots had 2080 and $700 \mathrm{~kg} \cdot \mathrm{ha}^{-1}$ of yield in the dry and wet seasons, respectively. Very low grain yield in the wet season was mainly due to a longer weed infestation period. In the dry season, hand weeding was performed at 35 DAP in the nontreated plots. It was observed that this weed infestation period (until 35 DAP) was not enough in the dry season; therefore, the hand weeding in the wet season was extended to 60 DAP. As explained earlier, weed biomass in the dry season in the nontreated control was only $3 \mathrm{~g} \cdot \mathrm{m}^{-2}$ at 60 DAP, whereas, in the wet season, weed biomass was $329 \mathrm{~g} \cdot \mathrm{m}^{-2}$. The higher weed biomass in the wet season was mainly responsible for the lower yield in the nontreated plots in the wet season. One hand weeding was performed in the nontreated (weedy control) plots because growers in irrigated areas do not leave their rice fields infested with weeds throughout the season [13,14]. Growers use at least one method of weed control. In addition, a DSR crop infested with weeds throughout the growing season may result in greater than $90 \%$ yield loss and, sometimes, total crop failure [15]. Grain yield in both seasons was similar between the herbicide-treated and weed-free plots (Table 3). These plots had 2620 - 2660 and $3250-3430$ $\mathrm{kg} \cdot \mathrm{ha}^{-1}$ of grain yield in the dry and wet seasons, respectively. Similar grain yield between the plots treated with herbicides and weed-free plots suggests that the sequential application of oxadiazon as PRE and a commercial mixture of fenoxaprop plus ethoxysulfuron as POST effectively controlled weeds at the experimental site. In previous reports, too, oxadiazon was suggested as one of the effective PRE herbicides to control annual grasses and broadleaf weeds in DSR systems [16-19]. Fenoxaprop plus ethoxysulfuron can effectively control a broad spectrum of weed flora, including Chinese sprangletop [Leptochloa chinensis (L.) Nees], which is hard to control by bispyribac-sodium, a commonly used POST herbicide in rice [20].

Grain yield was not affected when basal fertilizer was banded within or between rows (Table 3). However, grain yield decreased when basal fertilizer was broadcast on the soil surface. In the dry season, grain yield in the broadcast treatment $\left(2200 \mathrm{~kg} \cdot \mathrm{ha}^{-1}\right)$ was significantly lower than with the other fertilizer placement methods. In the wet season, however, grain yield was similar between
Table 3. Effect of weed control and fertilizer placement method on rice grain yield in the dry (DS12) and wet seasons (WS12) of 2012.

\begin{tabular}{|c|c|c|}
\hline \multirow{3}{*}{ Treatments } & \multicolumn{2}{|c|}{ Grain yield } \\
\hline & DS12 & WS12 \\
\hline & \multicolumn{2}{|c|}{$\longrightarrow \mathrm{kg} \cdot \mathrm{ha}^{-1} \longrightarrow$} \\
\hline \multicolumn{3}{|c|}{ Weed control } \\
\hline Herbicide-treated & 2660 & 3250 \\
\hline Nontreated & 2080 & 700 \\
\hline Weed-free & 2620 & 3430 \\
\hline $\mathrm{LSD}_{0.05}$ & 220 & 470 \\
\hline \multicolumn{3}{|c|}{ Fertilizer placement } \\
\hline Between narrow rows & 2530 & 2650 \\
\hline Between uniform rows & 2540 & 2590 \\
\hline Within uniform rows & 2500 & 2390 \\
\hline Broadcast & 2200 & 2200 \\
\hline $\mathrm{LSD}_{0.05}$ & 220 & 320 \\
\hline
\end{tabular}

the plots in which basal fertilizer was banded within uniform rows $\left(2390 \mathrm{~kg} \cdot \mathrm{ha}^{-1}\right)$ or broadcast on the soil surface $\left(2200 \mathrm{~kg} \cdot \mathrm{ha}^{-1}\right)$.

The results of our study demonstrated that rice yield was usually lower with surface broadcast of fertilizer than with subsurface fertilizer treatments. Similar results have been reported in a previous study in Canada, in which wheat yield when competing with weeds was often greater with subsurface $\mathrm{N}$ treatments than with surfacebroadcast $N$ [9]. In another similar study, spring wheat yield when competing with green foxtail or wild mustard [Brassica kaber (Dc.) L.C. Wheeler] was greater with point-injected $\mathrm{N}$ than with broadcast $\mathrm{N}$ in four of six cases [21]. Wheat grain yield after broadcast application of $45 \mathrm{~kg} \cdot \mathrm{N} \cdot \mathrm{ha}^{-1}$ was significantly lower than with deep banding of $\mathrm{N}$ fertilizer [22]. In conclusion, surface broadcast of basal fertilizer may result in high weed pressure in DSR systems. Therefore, there is a need to evaluate different seed drills capable of banding basal fertilizer within or between rows. Different fertilizers with suitable granular size should also be tested under DSR systems. Labor is becoming scarce in Asia and basal fertilizer application using seed drills would also help to reduce the labor requirement and increase fertilizer-use efficiency.

\section{Acknowledgements}

The authors would like to thank the Climate Unit, Inter- 
national Rice Research Institute, Los Baños, Philippines, for providing the weather data.

\section{REFERENCES}

[1] B. S. Chauhan, "Weed Ecology and Weed Management Strategies for Dry-Seeded Rice in Asia," Weed Technology, Vol. 26, No. 1, 2012, pp. 1-13. doi:10.1614/WT-D-11-00105.1

[2] B. S. Chauhan, G. Mahajan, V. Sardana, J. Timsina and M. L. Jat, "Productivity and Sustainability of the RiceWheat Cropping System in the Indo-Gangetic Plains of the Indian Subcontinent: Problems, Opportunities, and Strategies," Advances in Agronomy, Vol. 117, No. 1, 2012, pp. 315-369.

doi:10.1016/B978-0-12-394278-4.00006-4

[3] B. S. Chauhan and D. E. Johnson, "The Role of Seed Ecology in Improving Weed Management Strategies in the Tropics," Advances in Agronomy, Vol. 105, 2010, pp. 221-262. doi:10.1016/S0065-2113(10)05006-6

[4] K. J. Kirkland and H. J. Beckie, "Contribution of Nitrogen Fertilizer Placement to Weed Management in Spring Wheat (Triticum aestivum)," Weed Technology, Vol. 12, No. 1, 1998, pp. 507-514.

[5] J. M. DiTomaso, “Approaches for Improving Crop Competitiveness through the Manipulation of Fertilization Strategies," Weed Science, Vol. 43, 1995, pp. 491-497.

[6] R. E. Blackshaw, G. Semach, X. Li, J. T. O'Donovan and K. N. Harker, "Tillage, Fertilizer and Glyphosate Timing Effects on Foxtail Barley (Hordeum jubatum) Management in Wheat," Canadian Journal of Plant Science, Vol. 80, No. 3, 2000, pp. 655-660. doi:10.4141/P99-132

[7] H. L. Carlson and J. E. Hill, "Wild Oat (Avena fatua) Competition with Spring Wheat: Effects of Nitrogen Fertilization," Weed Science, Vol. 34, No. 1, 1986, pp. 29-33.

[8] B. Melander, A. Cirujeda and M. H. Jørgensen, "Effects of Inter-Row Hoeing and Fertilizer Placement on Weed Growth and Yield of Winter Wheat," Weed Research, Vol. 43, No. 6, 2003, pp. 428-438. doi:10.1046/j.0043-1737.2003.00359.x

[9] R. E. Blackshaw, L. J. Molnar and H. H. Janzen, "Nitrogen Fertilizer Timing and Application Method Affect Weed Growth and Competition with Spring Wheat," Weed Science, Vol. 52, No. 5, 2004, pp. 614-622. doi:10.1614/WS-03-104R

[10] A. P. Everaarts, "Response of Weeds to the Method of Fertilizer Application on Low-Fertility Acid Soils in Suriname," Weed Research, Vol. 32, No. 5, 1992, pp. 391397. doi:10.1111/j.1365-3180.1992.tb01900.x

[11] GenStat 8.0, "GenStat Release 8 Reference Manual," VSN International, Oxford, 2005, p. 343.
[12] D. C. Thill, J. T. O’Donovan and C. A. Mallory-Smith, "Integrated Weed Management Strategies for Delaying Herbicide Resistance in Wild Oats," Phytoprotection, Vol. 75, No. (Suppl.), 1994, pp. 61-70. doi:10.7202/706072ar

[13] B. S. Chauhan, V. P. Singh, A. Kumar and D. E. Johnson, "Relations of Rice Seeding Rates to Crop and Weed Growth in Aerobic Rice," Field Crops Research, Vol. 121, No. 1, 2011, pp. 105-115. doi:10.1016/j.fcr.2010.11.019

[14] G. Mahajan and B. S. Chauhan, "Effects of Planting Pattern and Cultivar on Weed and Crop Growth in Aerobic Rice System," Weed Technology, Vol. 25, No. 4, 2011, pp. 521-525. doi:10.1614/WT-D-11-00025.1

[15] B. S. Chauhan and D. E. Johnson, "Row Spacing and Weed Control Timing Affect Yield of Aerobic Rice," Field Crops Research, Vol. 121, No. 2, 2011, pp. 226-231. doi:10.1016/j.fcr.2010.12.008

[16] K. Ampong-Nyarko and S. K. De Datta, "A Handbook for Weed Control in Rice," International Rice Research Institute, Los Baños, Philippines, 1991, p. 113.

[17] B. S. Chauhan and S. B. Abugho, "Weed Management in Mechanized-Sown, Zero-Till Dry-Seeded Rice," Weed Technology, Vol. 27, No. 1, 2013, pp. 28-33. doi:10.1614/WT-D-12-00088.1

[18] B. S. Chauhan and J. Opeña, "Effect of Tillage Systems and Herbicides on Weed Emergence, Weed Growth, and Grain Yield in Dry-Seeded Rice Systems," Field Crops Research, Vol. 137, No. 1, 2012, pp. 56-69. doi:10.1016/j.fcr.2012.08.016

[19] D. B. Ishaya, S. A. Dadari and J. A. Y. Shebayan, "Evaluation of Herbicides for Weed Control in Three Varieties of Upland Rice (Oryza sativa L.) in the Nigerian Savannah," Crop Protection, Vol. 26, No. 10, 2007, pp. 14901495. doi:10.1016/j.cropro.2006.12.015

[20] B. S. Chauhan and S. B. Abugho, "Effect of Growth Stage on the Efficacy of Postemergence Herbicides on Four Weed Species of Direct-Seeded Rice," The Scientific World Journal, 2012, Article ID: 123071, 7 p.

[21] R. E. Blackshaw, G. Semach and H. H. Janzen, "Fertilizer Application Method Affects Nitrogen Uptake in Weeds and Wheat," Weed Science, Vol. 50, No. 1, 2002, pp. 634-641. doi:10.1614/0043-1745(2002)050[0634:FAMANU]2.0.C $\mathrm{O} ; 2$

[22] V. L. Cochran, L. A. Morrow and R. D. Schirman, "The Effect of N Placement on Grassweeds and Winter Wheat Responses in Three Tillage Systems," Soil Tillage Research, Vol. 18, No. 4, 1990, pp. 347-355. doi:10.1016/0167-1987(90)90119-X 